\title{
"Não Há Ninguém": \\ Violências contemporâneas e lugares de fala na cena performática
}

\author{
Mateus Junior Fazzioni \\ Universidade Federal de Santa Maria - UFSM, Santa Maria, Brasil \\ E-mail: mateusfazzioni15@gmail.com \\ Marcia Berselli \\ Universidade Federal de Santa Maria - UFSM, Santa Maria, Brasil \\ E-mail: bersellimarcia@gmail.com \\ Diego de Medeiros Pereira \\ Universidade do Estado de Santa Catarina - UDESC, Florianópolis, Brasil \\ E-mail: diego_ccac@hotmail.com
}

\section{Resumo}

O presente texto trata das ações performáticas realizadas no projeto "Violências contemporâneas e Criação em Ciclos: investigações de processos colaborativos", do Grupo de Pesquisa Laboratório de Criação - LACRI (CNPq/UFSM). Unindo professores e estudantes de teatro, o projeto propunha a criação, em modo colaborativo, de um acontecimento cênico a partir da temática "violências". Dos laboratórios semanais, em que se investigava a estratégia de criação Cycles Repère, emergiu o trabalho "Não há ninguém" (2018). As reflexões que seguem intentam discutir, à luz das teorias sobre a cena performática, a construção de um discurso poético permeado pelos lugares de fala dos performers.

Palavras-chave

Processo Colaborativo. Criação em Ciclo. Cena Performática. Lugar de Fala.
Abstract

This paper deals with the performative actions realized in the project "Violências contemporâneas e Criação em Ciclos: investigações de processos Colaborativos", by the Grupo de Pesquisa Laboratório de Criação - LACRI (CNPq/UFSM). Joining theater professors and students, the project proposed the creation, in a collaborative way, of a scenic event based on the theme of "violence". From the weekly laboratories investigating the Cycles Repère strategy of creation, the work "Não há ninguém" (2018) emerged. The reflections that follow try to discuss, in the light of the theories about the performative scene, the construction of a poetic discourse permeated by the places of speech of the performers.

Keywords

Collaborative Process. Creation Cycles. Performative Scene. Places of Speech. 


\section{Introdução}

Investigações a respeito dos estudos teatrais "pós-dramáticos", assim chamados por Hans-Thies Lehmann (2007), trouxeram consigo alterações significativas nos modos de operacionalização da cena contemporânea. Com isso, as implicações dos corpos dos sujeitos ganharam novas dimensões de análise de suas ações, tanto na cena como fora dela. Diariamente, somos atravessados por informações e anúncios a respeito de diferentes técnicas que possibilitam diferentes performances do corpo.

É notável que com esses desdobramentos teóricos e práticos, o corpo ganhou outras perspectivas na cena, ocupando o lugar que antes era do "universo dramático", da personagem, da mimese, trazendo aos processos artísticos uma hibridização de fronteiras e conceitos, assim como de diferentes discussões e discursos que emergem dos artistas da cena.

Diante dessas mudanças de paradigmas, no ano de 2018, professores e estudantes, vinculados ao Departamento de Artes Cênicas da Universidade Federal de Santa Maria, passaram a investigar um processo de criação em modo colaborativo por meio do Grupo de Pesquisa Laboratório de Criação - LACRI (CNPq/UFSM) ${ }^{1}$. As investigações tiveram como centro de gravidade a temática da violência, o que gerou o projeto "Violências contemporâneas e Criação em Ciclos: investigações de processos Colaborativos".

Os encontros aconteciam semanalmente nas quintas-feiras a noite no que chamamos de laboratório de criação. O grupo se propôs a investigar a estratégia de criação

\footnotetext{
10 Laboratório de Criação (Lacri) é um grupo de pesquisa que intenta aproximar professores e estudantes dos Cursos de Licenciatura em Teatro e Bacharelado em Artes Cênicas da UFSM: Licenciatura em Teatro da UDESC, artistas formados e em formação, buscando que seus diferentes repertórios alimentem e estimulem o processo de criação de um acontecimento cênico.
}

Cycles Repère desenvolvida por Jacques Lessard$^{2}$. Essa abordagem em ciclos inicia com a exploração de recursos sensíveis, seguida do estabelecimento de partituras/ composições que, posteriormente, são retomadas e avaliadas para a elaboração de um acontecimento cênico. No caso do LACRI, geramos o acontecimento cênico intitulado "Não há ninguém", que ocorreu no dia 22 de novembro de 2018, o qual foi permeado por discussões sobre o corpo, o lugar de fala dos artistas e sobre as violências contemporâneas acometidas e praticadas diariamente.

Durante o processo de criação, alguns pontos chamaram nossa atenção para a análise e um deles diz respeito ao objeto de discussão do presente artigo: os momentos performáticos presentes na construção da cena. No decorrer do processo de criação percebemos que o modo de operação em ciclos, estimulado pelos Cycles Repère, oferecia uma maior liberdade de apropriação e criação das cenas pelos atores/performers. Nesse sentido, mesmo com partituras formadas os atores eram convocados, semanalmente, a reelaborar, acrescentar, reestruturar e reconstruir os discursos da cena. Com isso, passamos a assumir um lugar de fala, trazendo para a cena os nossos discursos, técnicas incorporadas ao nosso repertório corporal, experiências artísticas e de vida para estarem em relação no processo colaborativo.

No presente texto, buscamos discutir

\footnotetext{
2 Jacques Lessard desenvolveu os Cycles Repère a partir de seu contato com outra estratégia de criação, The RSVP Cycles, a qual conheceu durante os San Francisco Dancer's Workshops realizados por Anna e Lawrence Halprin. Lessard buscava estabelecer uma proposta de criação cênica na qual os atores fossem criadores a partir de recursos e não de ideias. Para saber mais sobre a origem dos Cycles Repère e sua relação com The RSVP Cycles, consultar BERSELLI, M. Desafios da diferença: possibilidades de uma cena inclusiva a partir das relações estabelecidas entre os colaboradores no processo de criação - uma análise da estratégia de criação Cycles Repère. Anais $X$ Congresso da ABRACE, v. 19, n. 01, 2018. Disponível em https://www.publionline.iar. unicamp.br/index.php/abrace/index. Acesso em 19 jul., 2019
} 
como os momentos performáticos eram espaços abertos, agenciados pelos criadores - atores/performers - já que esses assumiram um lugar de fala na construção da cena e na elaboração de discursos poéticos do e no corpo.

Tendo em vista as discussões sobre as violências contemporâneas (e questionamentos como: o que são as violências contemporâneas e como a nossa violência acometida ou praticada surge em cena?), compreendemos os motes do processo de criação e, a partir disso, apresentamos as reflexões sobre como tais violências atravessaram nossos corpos e incitaram a elaboração de discursos poéticos permeados, também, de questões éticas e políticas.

\section{O projeto: em busca das violências} "escondidas"

Cotidianamente consumimos violência. Somos constantemente bombardeados por vídeos na internet, por notícias ou por manchetes em jornais em que a violência passa por um processo de espetacularização e ficcionalização. Somos expostos, é fato, mas também alimentamos uma certa estrutura de espetacularização da violência mediante imagens e vídeos que compartilhamos nas redes sociais. Criticamos a violência, mas de alguma forma, também somos atraídos por ela. Tornamo-nos espectadores prontos para difundir o que se apresenta diante de nós, mas de maneira distante e com certo afastamento como se não fôssemos, também, atores sociais desses acontecimentos.

Quando pensamos em tratar das violências contemporâneas fomos levados a questionar o que são essas violências, já que, muitas vezes, tratamos a violência como esse algo "alheio", distante do nosso corpo e que, portanto, só passa a existir quando nos afeta diretamente. Contudo, parece-nos importante pensar que a violência contem- porânea é a nossa violência cotidiana, é a violência que sofremos e que praticamos em todas as esferas em diferentes proporções.

Como aponta Farias, acabamos por renunciar a responsabilidade sobre as ações violentas e passamos a tratá-las como agentes externos, anulando assim

[...] qualquer possibilidade de enxergar a violência que habita cada um de nós, na esperança de que aqueles que estão no comando da produção de situações de violências sejam hábeis também no sentido de encontrar uma solução para os impasses surgidos. Com isso, nos distanciamos da questão de forma cômoda e atribuímos a pessoas a competência e a responsabilidade para produzir soluções, como se tudo o que concerne ao humano não fosse uma empreitada de cada um. (FARIAS, 2014, p. 18)

Pensando nas discussões propostas no Laboratório de Criação (LACRI) a respeito das violências contemporâneas, é possível reconhecer que os integrantes do coletivo fazem parte de algum grupo de "minoria" social estigmatizada: LGBTQI+, mulheres e artistas. "Minorias" essas em contato diário com situações de violência, explícitas ou implícitas.

Quando falamos em sofrer uma violência, não estamos nos referindo apenas à violência física; mas, sim, a todos os tipos de violências: físicas, psicológicas e/ou simbólicas. Quando temos como referência os grupos estigmatizados em que estamos inseridos na sociedade, compreendemos que a violência contra uma pessoa desses grupos é também uma violência contra cada um de nós e nossa existência. Por exemplo, a morte de um menino gay do outro lado do país, afeta-nos e retira "de campo" alguém que estava do nosso lado. Essas violências geram medo, repressão e instabilidade emocional e social.

Muitas vezes nós nos eximimos da responsabilidade de discutir a violência, anulamo-nos para não pôr em evidência as prá- 
ticas e ações violentas do meio social em que habitamos. Logo, percebemos que para traçar um caminho transversal e transformar esse descaso em discussão, temos que compreender o tema das violências contemporâneas como algo que nos perpassa e, como artistas, podemos (e talvez até devemos) expor inquietações e temas que necessitam ser urgentemente discutidos.

\section{O procedimento e o processo: cycles repère como estímulo aos discursos poéticos}

O processo de criação do acontecimento cênico "Não há Ninguém" foi balizado pelo procedimento de criação Cycles Repère, no qual a criação é impulsionada por um recurso sensível e em que as emoções são mais importantes do que as ideias. A proposta destaca quatro estágios: Recurso, Exploração, Avaliação e Representação.

O procedimento de criação em ciclos coloca o ator enquanto criador central no processo criativo, sem a dependência de uma situação pré-estabelecida ou texto dramático. Na relação com os recursos sensíveis determinados, e em contato com os demais participantes do coletivo, as improvisações destacam as inteligências criativas, desejos e interesses de cada colaborador. Certamente, o tema das violências contemporâneas e o procedimento de criação em ciclos, possibilitaram o estabelecimento de um discurso mais pessoal e real em cena, convidando, assim, os agentes criadores (atores/atrizes/performers) a assumirem um lugar de fala performativo na cena para tratar sobre as violências sofridas e reproduzidas.

O processo foi estruturado a partir de duas funções principais, quais sejam a atuação, ocupada por 05 atrizes/atores e a encenação ocupada por 02 encenadoras. Os estímulos partiam das encenado- ras para os agentes criadores, na forma de tarefas, seguindo a estrutura dos quatro ciclos. Um dos princípios dos Cycles Repère, destacado por Lessard em entrevista à Philippe Soldevila, é que o coletivo respeite as premissas de cada estágio:

O "processo" supõe e suporta uma grande mobilidade, exceto que quando se está em um estágio - e é, creio eu, a força dos Cycles -, é preciso respeitar os axiomas que lhe são próprios. Se estivermos no estágio de Recurso, não faremos a Avaliação e, se estivermos no estágio de Exploração, não rejeitaremos nada. Mas quando estamos na Avaliação, então sabemos o que podemos nos permitir, em vez de tudo fazer todo o tempo não importa como. Sabemos em que momento da criação estamos e, sabendo disso, conseguimos ter um maior controle do processo criativo. (LESSARD apud SOLDEVILA, 1989 , p. 36, trad. nossa $\left.^{3}\right)$

Assim, no primeiro encontro de criação, como parte do primeiro estágio dos ciclos, foi solicitado que os agentes criadores escoIhessem e apresentassem ao coletivo recursos sensíveis.

Re - Recurso/Ressource (ciclo 1): quando o grupo está pronto e definiu seus objetivos, cada participante apresenta sugestões, seus recursos, as "fontes sensíveis". Trata-se de um recurso que toque o criador, que o impulsione à criação. Os recursos podem ser de naturezas muito diferentes, como, por exemplo, um objeto, um som, um livro, uma performance, um texto, um poema. (BERSELLI et al., 2018, p. 101).

3 No original: "Le «processus» suppose et supporte une grande mobilité, sauf que lorsqu'on en est à une étape - et c'est, je crois, la force des Cycles - , on doit respecter les axiomes qui lui sont propres. Si on en est à l'étape Ressource, on ne fera pas d'Évaluation, et si on est à l'étape Partition, on ne rejette rien. Mais quand on en est à l'Évaluation, alors on sait ce qu'on peut se permettre, au lieu de tout faire tout le temps n'importe comment. On sait à quel moment de la création on en est et, sachant cela, on parvient à avoir un plus grand contrôle du processus créateur." 
Os recursos apresentados pelo grupo foram: um chapéu, um cinto de couro, uma bolsa, um trecho de um texto literário ${ }^{4}$, duas máscaras tapa-olhos e um espelho. A partir deles, tarefas como a manipulação de objetos, o contar situações do cotidiano e o desenvolver deslocamentos partiturizados eram indicadas pelas encenadoras. Desenvolvia-se, dessa forma, o segundo estágio dos ciclos: a exploração.

p - exploração/partition (ciclo 2): exploração do recurso a partir de improvisações. Inicia com a partitura exploratória (colocada ou não no papel). Nesta fase os recursos são compreendidos como pontos de partida para as criações, que são livres e podem tomar diversos rumos. Durante a exploração criativa muito material pode ser desenvolvido, e os participantes tomam notas breves do que for criado, dando origem à partitura sintética (BERSELLI et al., 2018, p. 101)

$\mathrm{Na}$ articulação dos elementos da cena com os repertórios e técnicas particulares, tal qual a experienciada no processo aqui apresentado, os agentes criadores colocam seus corpos numa experiência de "arte do corpo", na qual este serve de instrumento para a criação de outras relações com o espaço-tempo. Nessa experiência, o ator coloca seu corpo, sem uma representação, mas também sem o corpo que assume no dia-a-dia. (COHEN, 2002).

Contudo, a criação da cena, o discurso e a execução das tarefas só se concretizam se os performers forem conscientes e disponíveis para assumirem um papel de criadores e compositores da cena. Nesse caso, é necessário que os performers assumam um estado de disponibilidade e de jogo, no qual interagem e criam relações entre si e com os elementos presentes no espaço de atuação, articulando a cena e fazendo o dis-

4 Fazes-me Falta, de Inês Pedrosa (2002): A obra foi lançada em portugal em 2002. No processo aqui citado, foi utilizada a edição brasileira-PEDROSA, Inãs. Fazes me falta. Rio de janeiro: Objetiva 2010. curso poético emergir do corpo e das ações.

Com o estímulo das encenadoras, que estruturavam os encontros escolhendo propostas iniciais para alavancar as criações, no estágio de exploração o material foi levantado sem restrições, ficando a avaliação do que foi desenvolvido reservada ao terceiro estágio.

e - avaliação/évaluation (ciclo 3): mo-
mento de avaliar e escolher o que per-
manece de tudo o que foi criado. Uma
avaliação coletiva. Cada participante
aponta o que guardou do material impro-
visado, o que achou interessante, aquilo
que Ihe chamou a atenção. Desta avalia-
ção toma forma uma partitura mais com-
pleta. (BERSELLI et al., 2018, p. 101)

A partir da avaliação, o coletivo analisou o material criado, procedendo à seleção do que seria retomado. Nessa avaliação, cada composição selecionada recebeu uma nomenclatura, de modo a ser facilmente reconhecida na retomada em sala de ensaio. Após a seleção geral, coube às duas encenadoras a estruturação dessas composições. Foram organizados quatro blocos, com uma média de 05 composições em cada.

$\mathrm{Na}$ retomada de cada bloco, em sala de ensaio, as encenadoras seguiam fazendo escolhas, ajustando as composições de acordo com o todo que ganhava forma. Foi um momento de exercício de distanciamento e olhar crítico, uma vez que algumas composições perdiam força dentro da estrutura proposta, enquanto que outras ganhavam maior destaque e outras, ainda, recebiam complementos através de elementos sonoros ou luminosos. Os atores e atrizes seguiam tendo liberdade para propor alterações a partir do jogo que se re-estabelecia no espaço de atuação.

Com a finalização da etapa de criações em sala de ensaio, chegou-se, então, ao quarto estágio dos ciclos nomeado representação (re-representation), no qual ocorre o compartilhamento com espectadores. 


\section{Cena performática: saber-ser}

Estar em cena sob a ótica de performercompositor da cena e do discurso - para falar de violência, pressupõe uma responsabilidade de "saber-ser" sobre o que se fala, como aponta Zumthor:

[...] performance implica competência. Mas o que é aqui competência? [...] $\mathrm{Na}$ performance, eu diria que ela é o saber-ser. É um saber que implica e comanda uma presença e uma conduta, um Dasein comportando coordenadas espaço-temporais e fisiopsíquicas concretas, uma ordem de valores encarnada em um corpo vivo. (ZUMTHOR, 2007, p. 31)

Saber-ser é saber o discurso que se assume. Ao assumir um discurso, seja um discurso textual ou não, os performers estão se posicionando e criando significados. É preciso assumir o modo de ser do "Dasein"5. Dasein é uma entidade do ser, contudo, diferente dos outros entes ${ }^{6}$ é inacabada e permite a compreensão de si mesmo por meio da sua existência em uma relação do ser com o mundo. "Dasein é o único ente a possuir um sentido, o único capaz de criar, desejar, construir, destruir, e tudo mais que demonstre sua total interação com a própria existência, o que não é possível nos demais entes" (ARAUJO, 2014, p. 203).

A existência por meio do Dasein é vista como um campo de possibilidades, onde nada está pronto e, assim, tudo está na esfera do possível. Dessa forma, só compreendemos nosso ser, sendo e existindo.

[...] tendo a compreensão de que nós, seres humanos somos o Dasein, o ser-aí, não nos importa, segundo a

5 Termo principal na filosofia existencialista do alemão Martin Heidegger, traduzido em português como "ser-aí" ou "ser-aí-no-mundo".

6 Entes são entendidos por Heidegger como seres simplesmente dados como acabados diante dos olhos. fenomenologia de Heidegger, o conteúdo que cada um possui, mas como esse conteúdo se apresenta através de cada um. (ARAUJO, 2014, p. 204)

Ou seja, todos nós somos seres humanos, mas cada um tem um jeito próprio, individualidades e particularidades e, por esse motivo, é preciso saber-ser, saber o conteúdo que possuímos, nosso lugar de fala, nossas violências (sofridas e praticadas) e de que forma articulamos esses materiais em um discurso poético. É nessa forma individual de ser que está a "relação Dasein-mundo", a qual nos permite compreender nós mesmos na existência, no tempo e no espaço.

Nós, enquanto seres-aí, nos relacionamos com o mundo de acordo com nossa forma, nosso jeito, e ao mesmo tempo, nos relacionamos com a forma de todas as outras pessoas. Todas essas relações nos trazem uma compreensão de nós mesmos justamente por conta dessa interação, pois somos obrigados a ser para o outro, e enquanto somos para o outro entendemos como somos. É justamente por isso que Heidegger diz que em nosso ser (sendo) está em jogo nosso próprio ser. Enquanto somos, nossa forma está em jogo, pois somos sempre para outro. Não podemos prever o que sai dessas relações, ainda que tenhamos intenções, nossas relações dependem de um outro e, assim, entramos no jogo Dasein-mundo, onde tudo é possível, e tudo depende de experiências. (ARAUJO, 2014, p. 204)

Dessa forma, ao ser em cena, executando ações, nós também somos para o outro; nesse ser-no-mundo e saber o discurso que é assumido, existe um outro, um sujeito da recepção. Nessa relação entre um ser e o outro, tudo é possível, ainda mais quando estamos falando de um acontecimento cênico de "teatro performativo", como aponta Féral, em que:

[...] estamos bem inseridos na performatividade do ator (e fora de um personagem), aquela da ação que se executa. $O$ 
espectador é confrontado com este fazer, com estas ações postas [colocadas], das quais só lhe resta, a si próprio, encontrar o sentido. (FÉRAL, 2009, p. 202)

Ao proferirmos um discurso corporal na cena performática, buscamos emancipar a linguagem do nosso corpo a fim de criar o discurso poético e, de certa forma, afetarmos o receptor do discurso. Criamos uma outra atmosfera, um outro espaço, no qual a performance acontece e questionamentos que geram possíveis reflexões no espectador são instaurados. Nesse ponto de interação entre performer (construtor do discurso poético) e receptor (espectador) ritualiza-se a relação entre ambos.

A prática poética se situa no prolonga-
mento de um esforço primordial para
emancipar a linguagem (então, virtual-
mente, o sujeito e suas emoções, suas
imaginações, comportamentos) desse
tempo biológico. [...] nesse esforço des-
perta uma consciência e se formaliza
o ritual, que ele funda e irriga com sua
energia. (ZUMTHOR, 2007, p. 48-49)

O performer assume a construção das cenas nos momentos performáticos e, ao mesmo tempo, assume uma responsabilidade sobre o discurso que emerge dessa cena. Isso porque o discurso não é pronto ou está inscrito como uma dramaturgia textual; mas, sim, surge no "aqui-agora" por meio do performer, seu corpo e os discursos que dele afloram. Nesse sentido, antes de oferecer soluções, significados e códigos prontos "[...] o performer instala a ambigüidade de significações, o deslocamento dos códigos, os deslizes de sentido. Trata-se, portanto, de desconstruir a realidade, os signos, os sentidos e a linguagem" (FÉRAL, 2009, p. 203-204).

O objetivo do performer, nesse caso, não é criar signos de um único sentido, mas explorar as ressignificações possíveis; no nosso caso, explorar as ressignificações das violências contemporâneas. Para isso, assumimos discursos poéticos de modo consciente a partir de materiais que se encontram latentes em nosso corpo. Ao assumir de forma performativa esse discurso responsável e consciente em cena, percebemos algo como o que nos fala Zumthor "[...] que a performance é o único modo vivo de comunicação poética" (2007, p. 34). Seja para assumir um discurso por meio de um texto e construirmos o momento performativo ou simplesmente criar um discurso no momento efêmero. Se esse discurso convocar o performer à experimentação, colocá-lo em um estado de "fazer" capaz de despertar nele um desejo de produzir efeitos e atravessamentos nos espectadores, esse discurso se tornará poético.

[...] duas espécies de práticas discursivas, uma [...] "poética", e uma outra, a diferença entre elas consiste em que o poético tem de profundo, fundamental necessidade, para ser percebido em sua qualidade e para gerar seus efeitos, da presença ativa de um corpo: de um sujeito em sua plenitude psicofisiológica particular, sua maneira própria de existir no espaço e no tempo e que ouve, vê, respira, abre-se aos perfumes, ao tato das coisas. Que um texto seja reconhecido por poético (literário) ou não depende do sentimento que nosso corpo tem. Necessidade para produzir seus efeitos; isto é, para nos dar prazer. É este, a meu ver, um critério absoluto. Quando não há prazer - ou ele cessa - o texto muda de natureza. (ZUMTHOR, 2007, p. 35)

A criação em ciclos serviu para a configuração de uma estrutura aberta e flexível, uma espécie de roteiro que guiou o acontecimento cênico; mas, ao mesmo tempo, possibilitou a existência de espaços performativos para os criadores exercerem a liberdade de criação e a articulação de discursos poéticos do corpo. Esses espaços e lacunas a serem preenchidas no decorrer do roteiro foram entendidos por nós como momentos performáticos na cena, nos quais os criado- 
res eram desafiados como performers a estarem em jogo direto com as materialidades da cena, com os demais performers, com 0 roteiro estabelecido e com os espectadores.

Dessa maneira, os agentes criadores jogaram com todos os elementos da cena e com seus próprios repertórios e técnicas agenciando-os para elaborar um discurso poético do e no corpo. O acontecimento cênico intitulado "Não há ninguém" se tornou, então, um lugar de fala, uma vez que ao tratar de violências contemporâneas estávamos discutindo as nossas violências acometidas e praticadas diariamente.

\section{Não há ninguém: reflexões a} respeito do lugar de fala

Esse acontecimento cênico foi desenvolvido durante $\mathrm{o}$ ano de 2018 e foi o primeiro trabalho do LACRI. Teve como encenadoras uma estudante do curso de Artes Cênicas (habilitação Direção Teatral) e uma professora do Departamento de Artes Cênicas e, na atuação, além de um professor do mesmo departamento, contou com quatro estudantes do curso de Licenciatura em Teatro. $\mathrm{O}$ primeiro compartilhamento ocorreu no mês de novembro do mesmo ano em um espaço aberto nas dependências da universidade.

"Não há ninguém" trouxe à cena provocações sobre violências presentes no cotidiano. A criação em ciclos convocou os atores e atrizes a construírem a cena nos momentos performáticos sem a representação de personagens assumindo um estado de performers, que segundo Cohen (2002) se afasta do "ator-intérprete" justamente por trazer à cena sua presença como pessoa. Os criadores apareceram em cena como pessoas atuantes em um espaço-tempo estabelecido; como artistas cênicos que são e estão presentes no espaço com seus corpos, executando ações e es- tabelecendo relações com os espectadores.

Figura 1: Não há ninguém

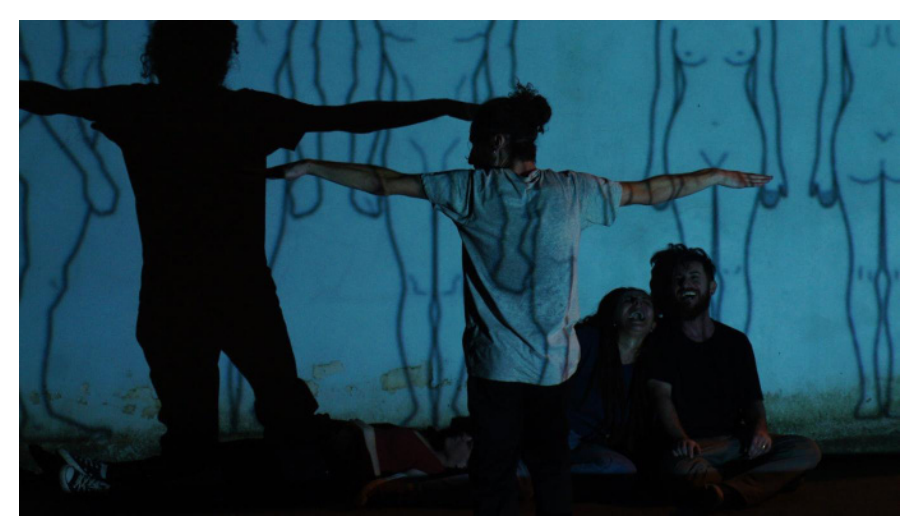

Acervo do projeto. Créditos Heverson Gonçalves. 22 nov., 2018

As cenas aconteciam com diferentes ações e discursos poéticos que surgiam dos corpos dos performers por meio do "trabalho em cima de suas habilidades, [...] físicas [...] ou totalmente intelectuais" (COHEN, 2002, p. 102-103) e a articulação dessas habilidades com as materialidades da cena (iluminação, sonoplastia, projeções audiovisuais, objetos etc.).

As ações desempenhadas pelos performers e articuladas com as materialidades da cena nos momentos performáticos do acontecimento cênico se tornaram discurso poético, uma vez que ao abordarmos diferentes violências nos colocamos como criadores, em um lugar de fala.

Esse lugar de fala, no acontecimento cênico "Não há ninguém", pode ser entendido como "uma declaração performativa daquilo que se é e daquilo que se acredita" (PETRONILIO, 2016, p. 53). Nesse sentido, o discurso poético que surgiu dos corpos em relação às materialidades assumiu uma perspectiva no lugar de fala, pois não era apenas um discurso retórico e vazio. $O$ discurso no lugar de fala passa, segundo Petronilio,

\section{[...] pelas sensações, pelas percepções}


e emoções. Pois falar é declarar o mais íntimo de si mesmo a ponto de se perder diante de uma multidão anônima. [...] $\mathrm{O}$ lugar de fala terá seu poder quando vier das entranhas, dos desejos, dos fluxos e refluxos da vida. O lugar de fala não se separa do fluxo de baba, de urina, de esperma, pois é desejo, é gozo, é vontade de potência. O lugar de fala é pura vontade de ser simplesmente aquilo que se é. (PETRONILIO, 2016, p. 53)

Nesse sentido, em nossa cena o discurso assumiu esse lugar de fala, pois buscamos dizer e afirmar por meio dos nossos corpos aquilo que somos e, assim, colocar em debate as violências que sofremos e as que também praticamos. Como aponta Cohen, "[...] o trabalho do performer é de 'levantar' sua persona. Isso geralmente se dá pela forma, de fora para dentro" (2002, p. 107). E ao tratar do tema "violências contemporâneas" os performers trouxeram seus repertórios e o seu lugar de fala para construir a cena nos momentos performáticos por meio do corpo.

Mesmo no lugar de fala, entretanto, nunca conseguimos dizer tudo:

[...] sempre estaremos em débito com algo que escapa, que vaza, que foge de nossa compreensão. Por isso é sempre importante assumir-se como um ato inacabado, como uma voz e um pensamento que está sempre em vias de se fazer. (PETRONILIO, 2016, p. 53)

Assim como o discurso poético do corpo do performer é efêmero, o lugar de fala só se concretiza no momento do "pôr em ação", está em "vias de se fazer". O "fazer" ou executar uma ação é o ponto principal dessa cena performativa, uma vez que o performer coloca "[...] seu corpo, seu jogo, suas competências técnicas [...]" (FÉRAL, 2009, p. 202) em um outro estado corporal, um estado de disponibilidade e atenção. A transformação do estado corporal em relação ao espaço e ao tempo presentes promove, também, uma alteração temporal e espacial do aqui-agora.
Figura 2: Não há ninguém

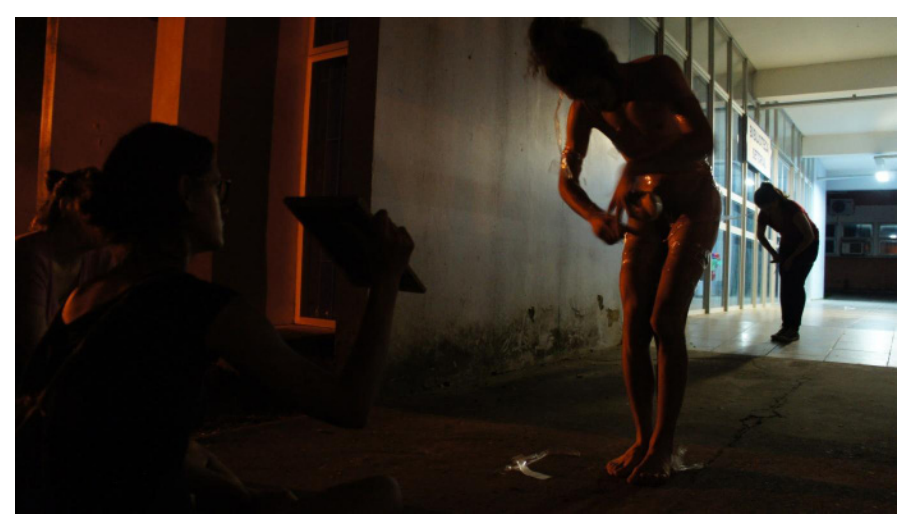

Acervo do projeto. Créditos Heverson Gonçalves. 22 nov., 2018

Existe uma proximidade entre performer e o espectador e, em virtude disso, existe um risco do real presente na cena. $O$ discurso poético que surge na cena por meio da fala ou de imagens influencia e atravessa o espectador. Dessa forma, assumir um discurso na cena performática "[...] é uma conduta na qual o sujeito assume aberta e funcionalmente a responsabilidade" (ZUMTHOR, 2007, p. 31-32).

Ainda que com grande responsabilidade, assumir um discurso em cena sobre violência, em um coletivo de artistas à margem - LGBTQI+ e mulheres - é uma forma política de exercer nosso ofício. Somos afetados pelo conteúdo do que compartilhamos, construindo um discurso dos e pelos nossos corpos e nossas palavras. Contudo, esse discurso só se torna poético porque as ações permitem uma contínua transformação implicada em singularidades de cada agente criador. Usamos do corpo na cena performativa para reconstruir um discurso pessoal e particular sobre as violências contemporâneas, o qual chamamos de poético por nos afetar e construir um sentido na cena mediante nosso corpo violentado. 
Figura 3: Não há ninguém

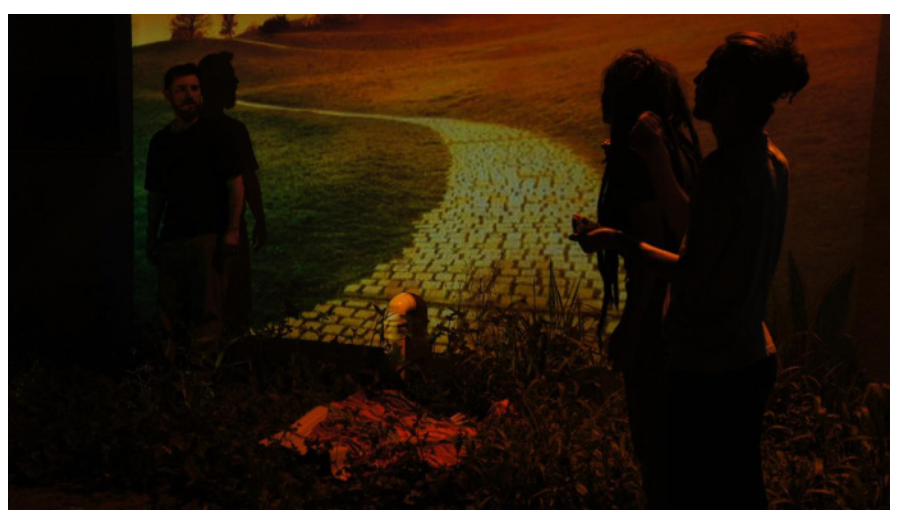

Acervo do projeto. Créditos Heverson Gonçalves. 22 nov., 2018

No segundo compartilhamento do nosso acontecimento cênico (maio de 2019) percebemos que os discursos já possuíam uma certa formalização; mas, ainda assim, recebiam influências do efêmero. Isso porque a relação entre performerlespectador nunca é a mesma, por conta da influência do real e do agora. Nesse espaço, onde o discurso formalizado é atravessado pelas influências do momento presente, ressignificamos nosso lugar de fala assim que o espectador confere a performatividade e a teatralidade da cena.

Em um momento em cena que contamos notícias de agressões contra crianças, nós assumimos textos jornalísticos para construir um discurso poético. E ele se torna poético pela liberdade de nos colocarmos sobre o texto. Em diálogo com Zumthor: "[...] com efeito, pode-se dizer que um discurso se torna de fato realidade poética (literária) na e pela leitura que é praticada por tal indivíduo" (2007, p. 24). Por conterem atrocidades, os textos noticiados nos tocam e nos impulsionam às ações seguintes em que performatizamos as percepções que temos daquelas notícias, como nos tocam, indignam e causam revolta.

Nosso discurso cênico busca o limite de aproximação com o espectador, instigando reflexões e transformações nesse. "Comunicar [...] não consiste somente em fazer passar informação; é tentar mudar aquele a quem se dirige; receber uma comunicação é necessariamente sofrer uma transformação" (ZUMTHOR, 2007, p. 52). Nesse caso, é preciso pensar que mais do que receber um discurso, o espectador pode ser levado a agir. Portanto, faz-se necessário a construção de um discurso poético, coerente e consciente, vivo no corpo do performer.

Não controlamos o impacto do nosso discurso sobre o espectador; o discurso pode chegar de maneira poética e afetar o espectador ou não. Existem inúmeras formas do indivíduo reagir ao discurso. Contudo, é importante perceber as reverberações do discurso e sua potência. O discurso apropriado pelo performer, transforma-se e é vivo nele, ao ponto que o corpo é o próprio discurso em cena, por meio da fala, dos gestos, das emoções e sensações emanadas etc.

Quando pensamos em momentos performativos em cena, constatamos que esses se alteraram de um dia para o outro, dentro de suas possibilidades de liberdade criativa. Nesse caso, cada dia é uma experimentação diferente, exigindo do performer uma capacidade de jogo em relação aos conteúdos apresentados ao espectador, levando a uma atualização do discurso poético.

\section{Considerações finais}

Todos os dias assumimos discursos construídos, assimilados e/ou reproduzidos. Nosso corpo é o próprio discurso que está intrínseco a quem somos. Dessa forma, como o ator/performer organiza o seu corpo (discurso) para que esse não seja uma simples reprodução do cotidiano? Como conciliar o real e ficcional do momento performático, uma vez que o discurso é real, dentro de um estado ficcional que o ator $e$ a atriz se propõem a estar? Quais as doses de ficção e de realidade que colocamos 
nos nossos atos performativos? É difícil saber quanto de ficção colocamos sobre as ações performáticas que realizamos em cena, ainda mais quando falamos a partir de nosso do lugar de fala e das violências contemporâneas que sofremos e causamos.

Tratar das violências contemporâneas não nos apresentou respostas do que são realmente essas violências, mas nos mostrou caminhos para discutir a violência em si; mostrou-nos que o corpo assume discursos e carrega em si marcas de suas vivências e experiências com as violências cotidianas. Ou seja, mesmo que tentemos nos afastar e nos eximir da violência, fazemos parte dela, reproduzindo, compartilhando ou sendo vítimas. A violência nos atravessa e fica marcada no nosso corpo, corpo esse que ao assumir um lugar de fala expõe e usa dessas marcas, juntamente com suas técnicas, para organizar um discurso poético, ético e político.

A construção dos discursos poéticos nos momentos performáticos foi possível graças ao meio de operação escolhido para o processo criativo - o Cycles Repère. Nos laboratórios semanais, ao colocarmos nossas emoções frente às ideias e pensamentos racionais, conseguimos deixar as marcas presentes em nosso corpo emergirem, ganharem a cena e o espaço para configurarem o acontecimento cênico.

As marcas desses corpos estigmatizados, tornaram-se lugares de fala, devido à liberdade criativa assumida pelos agentes criadores. Os atores/performers, por meio de suas técnicas, experiências e vivências em relação às materialidades da cena e aos demais performers, foram capazes de organizar e gerenciar esses elementos em seus corpos, tornando-os instrumentos de criação tanto das cenas como das relações que se estabeleciam durante o acontecimento.

A concretização dessas relações e dessa experiência do corpo e no corpo pressupôs, sobretudo, não só disponibilidade; mas, também, responsabilidade sobre os discursos assumidos. Ou seja, era preciso saber-ser em cena e saber o discurso que assumimos, uma vez que estar em cena pressupunha uma relação com os sujeitos da recepção que são confrontados com o que se apresenta a eles. Nesse sentido, é preciso enfatizar que a violência nunca foi escrachada em cena, pois percebemos que mais do que impor um discurso ao espectador, nossa proposição esteve sempre ligada à ideia de tornar a audiência ativa e deixá-la criar as suas significações dos nossos discursos e ir além.

Percebemos que é inevitável que o discurso poético da cena leve o espectador a associações e reflexões sobre o que seriam as violências contemporâneas e sobre as violências diárias presentes em sua vida. Quando pensamos sobre os discursos poéticos do corpo a respeito de um tema tão delicado e presente em todas as esferas, devemos levar em consideração que o espectador será afetado de alguma maneira.

Contudo, não sabemos o que essa afetação pode desencadear no espectador, seja revolta, tristeza, reconhecimento, lembrança, sofrimento ou transformação e, também, não temos como controlar isso, a não ser assumir um discurso sensível. A maneira que nos aproximamos do espectador também deve ser pensada, pois sabemos e acreditamos que intervir sobre esses sujeitos é preciso, mas de que forma? Afetar o outro também pode ser violento? Com dosar essas provocações? Seriam questões para uma posterior reflexão.

Em "Não há Ninguém” buscamos criar discursos poéticos potentes por meio de nossos corpos e da cena performativa intentando que os espectadores fossem afetados, incitados à reflexão e à ação. Vários questionamentos surgiram desse que fora nosso primeiro experimento. Novas portas 
se abrem, novos debates e discursos poéticos surgem, pois estamos vivendo a era da performatividade e, assim como ela, estamos em constante desconstrução e reconstrução, de ideias, conceitos e fronteiras.

\section{Referências}

ARAUJO, Marcus Vinícius Gomes de. Uma breve compreensão sobre o Dasein de Heidegger. Revista lampejo, Espírito Santo, n. 6, p. 200-206, fev. 2014.

BERSELli, Marcia et al. Processo colaborativo e a busca pela horizontalidade das relações entre as funções da cena: procedimentos, práticas e estratégias de criação. Conceição/Conception, [S.I.], v. 7, n. 2, p. 90115, dez. 2018.

COHEN, Renato. Performance como linguagem. São Paulo: Perspectiva, 2002.

FARIAS, Francisco, R. de. Quatro questionamentos sobre a violência. Rio de Janeiro: Contra Capa, 2014.

FÉRAL, Josette. Por uma poética da performatividade: o teatro performativo. Tradução: Lígia Borges. In: Sala Preta - Revista de Artes Cênicas, n. 8, p. 191-210. São Paulo: Departamento de Artes Cênicas, ECA/ USP, 2009.

HEIDEGGER, Martin. Ser e tempo, Trad. de Márcia Sá Cavalcante Schuback. $8^{a}$ ed. Petrópolis, RJ: Vozes, 1986.

LEHMANN, Hans-Thies. Teatro pós-dramático. São Paulo: Cosac Naify, 2007.
PETRONILIO, Paulo. "Lugar de Fala": o grau da performance e outras heterotopias. Revista Guará, Goiânia, v. 6, p. 39-59, jan./ dez. 2016

SOLDEVILA, Philippe. De l'architecture au théâtre: Entretien avec Jacques Lessard. Jeu, (52), p. 31-38, 1989.

ZUMTHOR, Paul. Performance, recepção e leitura. [Tradução de Jerusa Pires Ferreira e Suely Fenerich]. $2^{a}$ ed. São Paulo: Cosac Naify, 2007.

Recebido: $24 / 04 / 2019$

Aprovado: 22/10/2019 